Università degli Studi di Salerno

CENTRO DI ECONOMIA DEL LAVORO E DI POLITICA ECONOMICA

\author{
Adalgiso Amendola* - Floro Ernesto Caroleo* \\ Gianluigi Coppola***
}

\title{
Regional Disparities in Europe
}

\author{
*adamen@unisa.it- **caroleo@unisa.it- ${ }^{* * *}$ glcoppola@unisa.it \\ CELPE Centro di Economia del Lavoro e di Politica Economica \\ DISES Dipartimento di Scienze Economiche e Statistiche \\ Università degli studi di Salerno \\ Via Ponte Don Melillo - 84084 Fisciano (Salerno) Italy \\ www.celpe.unisa.it
}

DISCUSSION PAPER NUM. 78

January 2004 
CENTRO DI ECONOMIA DEL LAVORO E DI POLITICA ECONOMICA

Scientific Committee:

Adalgiso Amendola, Floro Ernesto Caroleo, Ugo Colombino, Cesare Imbriani, Pasquale Persico, Enrico Pugliese, Salvatore Vinci 


\section{Index}

Abstract

pag. 5

Introduction

page 7

1. Measuring disparities: Three way matrix

" " 10

2. The Statis Method

3. Analysis and Results

“ " 12

4. Summary and Conclusions

“" 14

References

“" 34

“ " 40 


\begin{abstract}
In the last decades, and particularly in the Nineties, The European Economy has been widely characterised by regional disparities. This paper aims to evaluate if different regional economic structures, such as productive mix and labour market composition, contribute to this disparities and to what extent they prevent the convergence and/or favour divergent clusters of regions. To this purpose we shall apply a multivariate analysis method, named STATIS, to a set of regional characteristic indicators that will allow us to estimate some latent factors which are able to measure the regional differences and their dynamic.
\end{abstract}

Keywords: European regional differences, Multivariate analysis, STATIS Jel code: R11, R58, J60 


\section{Introduction}

In recent years, because the disparities among regions prove significantly greater than those among countries, analysis of the causes of the socio-economic differences among the European regions has attracted increasing interest.

This strand of analysis has been prompted mainly by the fact that the creation of the European Union was based on the belief that a broader area of free trade would be a necessary and sufficient condition for economic welfare to spread uniformly among countries. The first question that arises is why theoretical explanations of regional differences fail to account satisfactorily for the European case in recent decades. Indeed, if the three theories - the neoclassical theory in both its 'strong' and 'weak' versions, the theory of endogenous development, and the 'new geography' approach - are taken to their extreme consequences, they point to the conclusion that regional differences are either bound to converge on a single development path in the long period (the neoclassical theory) or that they will diverge permanently, with the creation of strong polarization processes. ${ }^{1}$ As we have said, the regions of Europe display not only persistent differences but also a dynamic whereby periods of slow convergence alternate with others in which the tendency is towards divergence (Tondl, 1997; Cuadraro Rura, 2001).

The second question concerns policy. That is, the problem arises as to which regional, national or European strategy is best able to accelerate the process of convergence among regions. Regional cohesion has always been a priority objective of the European Union, which has allocated huge amounts of economic resources (the European Social Fund and the Cohesion Fund) to its achievement. And regional cohesion has become even more topical as a result of recent developments in the process of

\footnotetext{
${ }^{1}$ The literature on the subject is detailed and well known. Here we quote the valuable surveys by De la Fuente (2000) and the European Commission (2000).
} 
European integration. The advent of the single currency and the financial stability constraints imposed by the Maastricht Treaty inhibit the pursuit of independent monetary policies and drastically reduce the autonomy of member-states as regards their fiscal policy: and all this at a time when enlargement of the EU towards the East will soon radically extend the regional scope of the problems of economic and social cohesion. This European policy approach has been subject to widespread criticism (Boldrin and Canova, 2001; de la Fuente, 1999; Canova, 2001; Davies and Hallet, 2002 and 2001; Edervee and Gorter, 2002; Martin, 1998) on the grounds that, as we have seen, it is not supported by the facts and is directed at regional contexts with extremely diverse socio-economic features.

Finally, analysis of convergence-divergence processes pays increasing attention to the institutional mechanisms that regulate the labour market, as well as to the characteristics of the labour supply and demand and their dependence on spatial factors (Niebhur, 2002). The excessive rigidity and the scant mobility (Blanchard and Katz, 1992; Decréssin and Fatas, 1995; Obstfeld and Peri, 1998) of the labour factor are judged to be the main causes of the intensification - or the persistence - of divergence among regions. In fact, as is well known, the variables used to assess convergence/divergence are measures generally tied to per capita GDP (Sala-i-Martin, 1996; Barro and Sala-i-Martin, 1991) and to its two components of employment rate and productivity. Econometric estimates unanimously agree that, in recent years in Europe, the convergence of per capita GDP has been very slow and has instead fostered the formation of clusters of homogeneous regions which are internally convergent but diverge with respect to each other, and this has been due exclusively to the trend in the employment rate and therefore to the characteristics of the labour market (Overman and Puga 2002; Combes and Overman, 2003; Daniele, 2002; Basile, de Nardis and Girardi, 2003; Kostoris Padoa Schioppa and Basile, 2002; Kostoris Padoa Schioppa, 1999).

Examination has consequently been made of a series of regional factors connected with the labour market, some that are often complementary but sometimes concomitant, and which may 
potentially create, maintain or intensify divergence among regions (Erlhost, 2000): the endowment of factors and 'fundamentals'; the structure of the labour market - natural growth and the age composition of the population, the composition of the labour force (Genre and Gòmez-Salvador, 2002); migratory phenomena and commuting (Greenway, Upward and Wright, 2002); the employment level, gross regional product, market potentials, the sectoral mix (Marelli, 2003; Paci and Pigliaru, 1999; Paci, Pigliaru and Pugno, 2002); density and urbanization (Taylor and Bradley 1997); economic and social barriers, schooling levels - the institutional structure that regulates the goods and labour markets, or the composition of wages (Pench, Sestito and Frontini, 1999; Hyclack and Johnes 1987).

The aim of this paper is to apply a multivariate factorial analysis method (the STATIS method) which, we believe, lends itself well to verification of most of the phenomena just described. The STATIS method, in fact, enables the European regions to be 'read' on the basis of factors that sum up their main socioeconomic characteristics, to group them into homogeneous clusters, and to examine their temporal dynamics. It can therefore be used to estimate whether structural features favour the formation of clusters of regions and whether these display a tendency to converge either to a single structure or instead to a multiplicity of socio-economic structures. On this basis, it is then possible to investigate a number of themes: among them, whether the criteria used by the European Union to identify the regions to be targeted by the Structural and Cohesion Funds refer to homogeneous or diversified realities, and therefore whether they require more appropriate instruments.

The second section provides a brief description of the STATIS method. In the third, the method is applied to the European regions and analysis is conducted of the characteristics of the main clusters of regions and of their dynamics over time. The concluding section provides a summary of the results. 


\section{Measuring disparities: three-way matrices}

As we have seen, the disparities among regions (cases) can be studied on the basis of numerous indicators (variables), like per capita GDP, productivity and the employment rate, and they can also be measured in their temporal dynamics (time). The multidimensional nature of regional differences therefore lends itself well to analysis by means of multivariate analysis methods, and in particular by dynamic multivariate analysis.

We decided to apply the STATIS (Structuration des Tables $A$ Trois Indeces de la Statistique) method. This is a dynamic multivariate method which enables analysis of multidimensional (multiway) phenomena expressible in the form of three-way matrices: cases $i$, variables $j$, time $t$. The method has been developed by Escoufier (1985), and it has found numerous applications in economics, in Italy as well (D'Ambra, 1986; Fachin and Vichi, 1993; Tassinari and Vichi, 1994). Moreover, it has already been used to explain the dynamics of disparities among the Italian provinces (Amendola, Caroleo and Coppola, 1997; Baffigi, 1999).

This technique of exploratory analysis is based on study of a three-way data matrix $X_{I, J T}$ obtained from the temporal succession of data matrices ${ }_{t} X_{i, j}$ of the same order, where $i$ is the statistical unit and $j$ the variable, both of them relative to the period $t(i=1$, $2 \ldots I ; j=1,2 \ldots \mathrm{J} ; t=1,2 \ldots \mathrm{T})$. The formula is:

$$
?_{I, J T} ?\left\|_{1} X \quad{ }_{2} X \quad{ }_{T} X\right\|
$$

which can be presented as

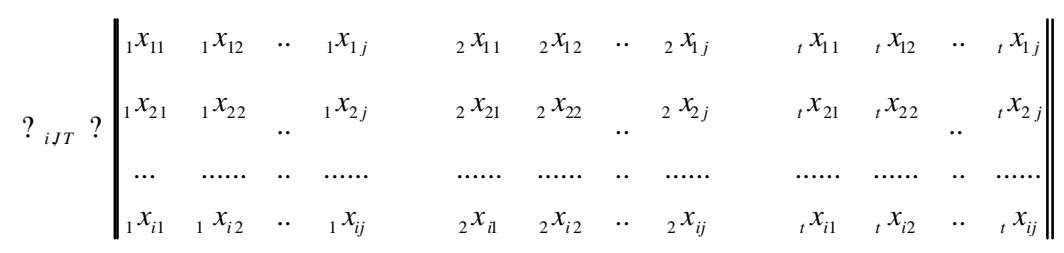


From the three-way matrix thus constructed it is possible to derive (Rizzi, 1989):

1. the variance-covariance matrix

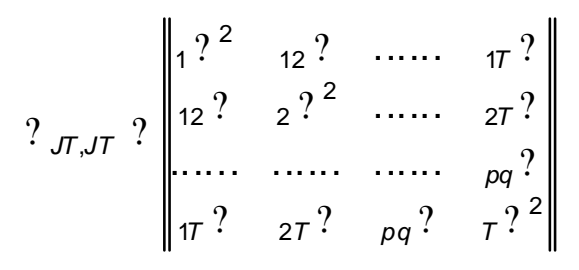

where ${ }_{p q}$ ? is the variance-covariance matrix between $p X_{i, j}$ and $q^{X} X_{i, j}:$

$$
{ }_{p q} ? ? ?_{p}^{?} \hat{X}_{i, j, q}^{\prime} \hat{X}_{i, j} \frac{\eta}{n}
$$

where $\hat{X}$ is the deviation matrix and $1 ? p ? T, 1 ? q ? T$.

The matrices on the main diagonal represent the variancecovariance matrices of the matrix ? ${ }_{I J T}$ at time $t$, while $p q$ ? measures the same relation between the variables relative to time $q$ and time $j$.

2. The (TxT) square matrix, $I_{T, T}$ where each generic element $I_{p, q} ? \operatorname{tr}\left({ }_{p q}\right.$ ? $) \quad$ corresponds to the trace of the relative submatrix ${ }_{p q}$ ? of ? $J T, J T$

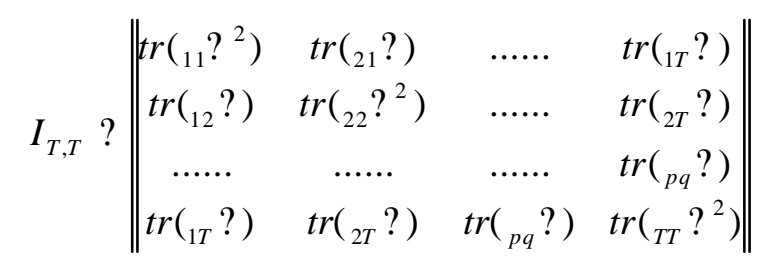

and is a measure of the dissimilarity between $p X_{i, j}$ /and ${ }_{q} X_{i, j .}$. The higher the value assumed by this index, the less the similarity between the structures of $p X_{i, j}$ and / $q X_{i, j}$. 
Alternatively, one may assume as the index of similarity Escoufier's (1976) coefficient:

$$
I_{p, q}^{*} ? R V\left({ }_{p} X_{i, j, q} X_{i, j}\right) ? \frac{\operatorname{tr}\left({ }_{p q}{ }_{p q} ?\right)}{\sqrt{\operatorname{tr}\left({ }_{p} ?^{2}\right) \operatorname{tr}\left({ }_{q} ?^{2}\right)}}
$$

obtained by operating with matrices of deviations from the mean, and which have the characteristic of varying between 0 and 1 . The coefficient, which can be considered a generalization of the Bravais correlation coefficient, is close to unity if the matrices have an almost identical structure.

\section{The STATIS method}

The STATIS method divides into three phases: Interstructure, Compromise and Intrastructure.

The purpose of the Interstructure phase is to identify a suitable vectorial space smaller than $T$, where the $T$ occasions can be represented.

To this end, examination is made of the matrix $I_{T, T}$ (also called the interstructure matrix), the column vectors of which are assumed as characteristic elements of each of the $T$ occasions. Constructed from this is a factorial subspace ? ${ }^{s}$ with $s<t$ generated by the $s$ eigenvectors corresponding to the $s$ largest eigenvalues of $I_{T, T}$. The subspace thus constructed yields the best representation of the $T$ occasions because it is demonstrated that the matrix $Q$, of rank $s$ ? $T$ - whose elements $Q_{(s)}$ ? ? ${ }_{a} u_{a} u_{a}^{\prime}$ are linear combinations of the first $?_{a}$ eigenvalues' and $u_{a}$ eigenvectors of the matrix $I_{T, T}$ - has the characteristic of minimizing the square of the Euclidean norm ??I-Q??.

A first result is thus obtained. The $T$ occasions with coordinates equal to $\sqrt{?_{1} u_{1}}, \sqrt{{ }_{2}{ }_{2} u_{2}}, \ldots \ldots \ldots . \sqrt{?_{h} u_{h}}$ can be generated in the factorial subspace ${ }^{s}$ by the first eigenvectors $u_{a}$. 
It is also possible to calculate indices relative to the quality of the representation, and also relative to the contribution made by each of the $T$ occasions:

- the ratio between the sum of the first $s$ eigenvalues and the total of all the eigenvalues constitutes a measure of the percentage of total information contained in the space ? ${ }^{s}$;

- the ratio between the individual eigenvalue and the overall total measures the variability captured by the relative eigenvector;

- the square of the cosine of the angle formed by the factorial axis with the segment that joins the occasion-point with the origin is an index of the representation quality of the individual occasion from that axis;

- the proximity of two occasion-points in the space ${ }^{s}$ is an indicator of the similarity of the matrices.

In the compromise phase, a fictitious structure or synthesis matrix is identified which optimally summarizes the information contained in the $T$ variance and covariance matrices. This structure, called 'compromise', is given by the matrix $W$ obtained as a linear combination of the elements $u_{1}$ of the eigenvector of the matrix $I_{T, T}$ corresponding to the highest eigenvector and the matrices ? $?_{t} ?_{t}{ }_{t}{ }^{\prime}$ (Escoufier, 1979, p. 113):

$$
W ? \stackrel{?}{?} u_{t ? 1} u_{t} ?_{t}
$$

In the space plotted by the $s$ eigenvectors corresponding to the first $s$ eigenvalues of the matrix $W$ it is possible to represent both the $j$ variables and the median positions of each individual. The latter are derived from the diagonalization of matrix $W$ obtained by identifying a matrix $M$ such that $W=M M D$ (where $D$ is a diagonal matrix defined positive whose elements are the weights of the individuals, statistical units, $D ? \frac{1}{L} I$, with $L$ equal to the number of individuals, and where $I$ is an identity matrix.

In other words, matrix $W$ is the best compromise, in the sense defined above, among the various representations that can be 
associated with each of the $T$ matrices taken separately for each unit of time.

If $s=2$, the representation occurs in a two-dimensional space corresponding to the first two factors identified. Obviously, this projection will be better, the greater the incidence of the first two eigenvectors on the trace of $W$.

In the intrastructure phase it is then possible to represent the trajectories followed in time by each individual in the factorial space thus identified. If only the first two eigenvalues are considered, the representation of the trajectories may occur in a space where the system of Cartesian axes is constituted by the eigenvectors $a_{1} a_{1}$ and $a_{2} a_{2}$, and where the coordinates on the first axis of each individual are given by $?{ }_{1 t} ? a_{1} ?^{? 0.5}$ and on the second axis by ? ${ }_{2 t} ? a_{2} ?^{? 0.5}$.

\section{Analysis and results}

The aim of this paper, as said, is to analyse the medium-term dynamics of the performance of labour markets and economic structures in the European regions. Used to this scope it is the dynamic method for principal components analysis - the STATIS method - described in the previous section. This method enables identification of criteria with which to cluster regions in various years using a base information structure consisting, besides labour market variables, of indicators on income, composition of the population, and the sectoral structure of employment. It is thus possible to study the change over time in the territorial dimension of interactions between labour market and economic development, and to analyse how the various regional units in question relate to this evolution.

The variables used for this analysis are listed in Table 3.2. They are taken from the Eurostat REGIO database and the European regions database of Cambridge Econometrics Ltd. and they are, as said, indicators characteristic of the labour market and the production system (Wishlade and Yuill, 1997). Labour demand is measured by the unemployment rate on the total working-age population (TOT), while the labour supply is measured by the 
labour-force participation rate (TAT). The percentage of the longterm unemployed (ULR) is used as a proxy for the structural gap between labour demand and supply. The percentage of part-time employment (PTT) is used as a measure of the flexibility of the regional labour market.

The production system is represented by four variables corresponding to the percentages of employed persons in agriculture (AGR), industry (IND), traditional services - commerce, hotels and non-market services (GHM) - and advanced services transport, financial services and others (IJA). This grouping of production sectors has been performed taking account of percentage variations in employment in individual sectors, and as regards services, of average labour productivity observed during the period examined. As Table 3.1 shows, between 1991 and 2001 in the European Union, the percentages of persons employed in agriculture and industry decreased, while they increased in the services sector. The latter divides sharply between advanced services, which recorded an average labour productivity above the European average, and traditional services, whose average productivity was instead below the European average.

The other variables considered are population density (DEN), as a proxy for the gravitational force of a region, and per capita income (PPS), which is the indicator most frequently used to represent regional disparities. 


\begin{tabular}{|c|c|c|}
\hline $\begin{array}{l}\text { Table } 3.1 \\
\text { Dynamics of employment and avera } \\
\text { production sector in the countries of } t \\
2000\end{array}$ & $\begin{array}{l}\text { age labour pro } \\
\text { the European } L\end{array}$ & $\begin{array}{l}\text { ductivity by } \\
\text { Jnion. 1991- }\end{array}$ \\
\hline Sector & $\begin{array}{l}\text { Percentage } \\
\text { change in } \\
\text { employment }\end{array}$ & $\begin{array}{l}\text { Labour } \\
\text { productivity } \\
\text { (period } \\
\text { average } \\
\text { thousands } \\
\text { of euros } \\
1995) \\
\end{array}$ \\
\hline Agriculture, Forestry and Fishing & -23.33 & 22,520 \\
\hline Other Manufacturing Activities (DD-DK) & -13.03 & 39,910 \\
\hline Textiles and Clothing (DB-DC) & -18.73 & 22,070 \\
\hline Electronics (DL) & -13.61 & 40,930 \\
\hline Transport Equipment (DM) & -15.70 & 46,580 \\
\hline Mining and Energy Supply $(\mathrm{C}+\mathrm{E})$ & -16.27 & 94,090 \\
\hline Food, Beverages and Tobacco (DA) & -8.44 & 47,960 \\
\hline Construction & -2.90 & 31,390 \\
\hline $\begin{array}{l}\text { Fuels, Chemicals, Rubber and Plastic } \\
\text { Products (DF-DH) }\end{array}$ & -7.20 & 64,410 \\
\hline Financial Services $(\mathrm{J})$ & 6.12 & 65,710 \\
\hline Other Financial Services (K) & 33.75 & 62,710 \\
\hline Transport and Communications (I) & 5.02 & 42,650 \\
\hline Non-market services & 8.94 & 33,530 \\
\hline Wholesale and Retail (G) & 11.44 & 29,070 \\
\hline Hotels and Restaurants $(\mathrm{H})$ & 20.59 & 25,730 \\
\hline TOTAL & 4.48 & 39,760 \\
\hline
\end{tabular}




\begin{tabular}{|c|c|c|c|}
\hline \multicolumn{4}{|c|}{$\begin{array}{l}\text { Tables } 3.2 \\
\text { Variables us }\end{array}$} \\
\hline$N$ & Code & Variable & Index \\
\hline 1 & DEN & Population density & Inhabitants /sq km \\
\hline 2 & TAT & total activity rate & $\begin{array}{l}\text { labour force/population } \\
\text { aged over } 15\end{array}$ \\
\hline 3 & TOT & employment rate & $\begin{array}{l}\text { employed/population aged } \\
\text { over } 15\end{array}$ \\
\hline 4 & ULR & $\begin{array}{l}\text { Long-term } \\
\text { unemployment rate }\end{array}$ & $\begin{array}{l}\text { long-term unemployed/total } \\
\text { unemployed }\end{array}$ \\
\hline 5 & PTT & $\begin{array}{l}\text { part-time employment } \\
\text { rate }\end{array}$ & $\begin{array}{l}\text { part-time employed/total } \\
\text { employed }\end{array}$ \\
\hline 6 & AGR & $\begin{array}{l}\text { percentage employment } \\
\text { in agriculture }\end{array}$ & $\begin{array}{l}\text { employed in agriculture/ } \\
\text { total employed }\end{array}$ \\
\hline 7 & IND & $\begin{array}{l}\text { percentage employment } \\
\text { in industry }\end{array}$ & $\begin{array}{l}\text { employed in industry/total } \\
\text { employed }\end{array}$ \\
\hline 8 & GHM & $\begin{array}{l}\text { percentage employment } \\
\text { in traditional services }\end{array}$ & $\begin{array}{l}\text { employed in retail trade, } \\
\text { hotels and non-market } \\
\text { services /total employed }\end{array}$ \\
\hline 9 & IJA & $\begin{array}{l}\text { percentage employment } \\
\text { in advanced services }\end{array}$ & $\begin{array}{l}\text { employed in transport, } \\
\text { financial and other } \\
\text { services/total employed }\end{array}$ \\
\hline 10 & PPS & per capita income & $\begin{array}{l}\text { per capita GDP in } \\
\text { Purchasing Power Standard }\end{array}$ \\
\hline
\end{tabular}

The European regions represent 130 cases. The level of territorial disaggregation of the European regions selected was intended to cover the entire territory and to provide the maximum disaggregation possible with the data available. This level corresponds to the Nuts 2 level for Greece, Spain, France, Italy, Austria and Portugal; Nuts 1 for Belgium, Germany, Holland, Finland, the United Kingdom; Nuts 0 for Denmark, Ireland, Luxembourg and Sweden, for which countries there are no Nuts 1 and Nuts 2 disaggregations (or data are not available with which to 
perform such disaggregations) ${ }^{2}$ (see Appendix). The time period is between 1991 and 2000 .

The STATIS methodology, as said, consists in the analysis of the three-way matrix (tXij), where $t$ denotes the temporal observations, $i$ the regions, and $j$ the variables, obtained by the succession of $\mathrm{T}$ matrices of the same dimensions.

As explained in the previous section, the analysis moves through three phases: interstructure, compromise and infrastructure. The output from the interstructure phase describes the structure of the $T$ matrices in a vectorial space smaller than $T$. This is reduced to two dimensions but still maintains a good similarity to the initial representation. The compromise phase consists in the estimation of a synthesis matrix which yields a representation, in the two-dimensional space identified, of the characteristic indicators and of the average positions of the regions in the time-span analysed (1991-2000). The result of this intrastructure phase is a representation of the trajectories followed by the individual regions in the same period of time.

In order to evaluate the goodness of the factorial representation yielded by construction of the compromise matrix, Table 3,3 shows the first three highest eigenvalues and the percentage of the total variance explained by the first three factorial axes.

\section{Table 3.3}

Eigenvalues and inertia percentages of the factorial axes

\begin{tabular}{r|r|r|r|}
\hline Axis & Eigenvalue & Variance explained & $\begin{array}{c}\text { Cumulated } \\
\text { variance } \\
\text { explained }\end{array}$ \\
\hline 1 & 3.75547 & 36.76 & 36.76 \\
\hline 2 & 1.99895 & 19.56 & 56.32 \\
\hline 3 & 1.18853 & 11.63 & 67.95 \\
\hline
\end{tabular}

To be noted first is that $36.8 \%$ of the variance is explained by the first factor, and $19.6 \%$ by the second, for a total of $56.3 \%$ of the

${ }^{2}$ The complete list of the 130 regions is given in the Appendix. 
variance expressed by the set of all the variables. In other words, the first factor alone explains more than one-third of the total variability, while the first three factors jointly explain almost $68 \%$. Consequently, the reduction of the phenomenon's variability, obtained by representing it in a two-dimensional space, is a meaningful synthesis of the information considered.

Figures 3.1 and 3.2 show, respectively on the factorial plane generated by the first two and by the first and third principal components, the positions of the average annual value of each of the ten characteristic indicators considered.

In order to interpret the two figures, we may refer to Table 3.4, which shows that minimum and maximum period values of the correlations between the variables and the factorial axes. It will be seen that the variables most closely correlated with the first factor are, on the one hand (negative quadrant), the employment rate (TOT), the activity rate (TAT), the percentage of part-time employment (PTT), per capita income (PPS), and the percentage of employment in advanced services; and on the other (positive quadrant), the percentage of long-term unemployment (ULR), and the percentage of employment in agriculture (AGR). In other words, along the first axis one observes a clear polarization between the labour market indicators and those relative to the production structure. 


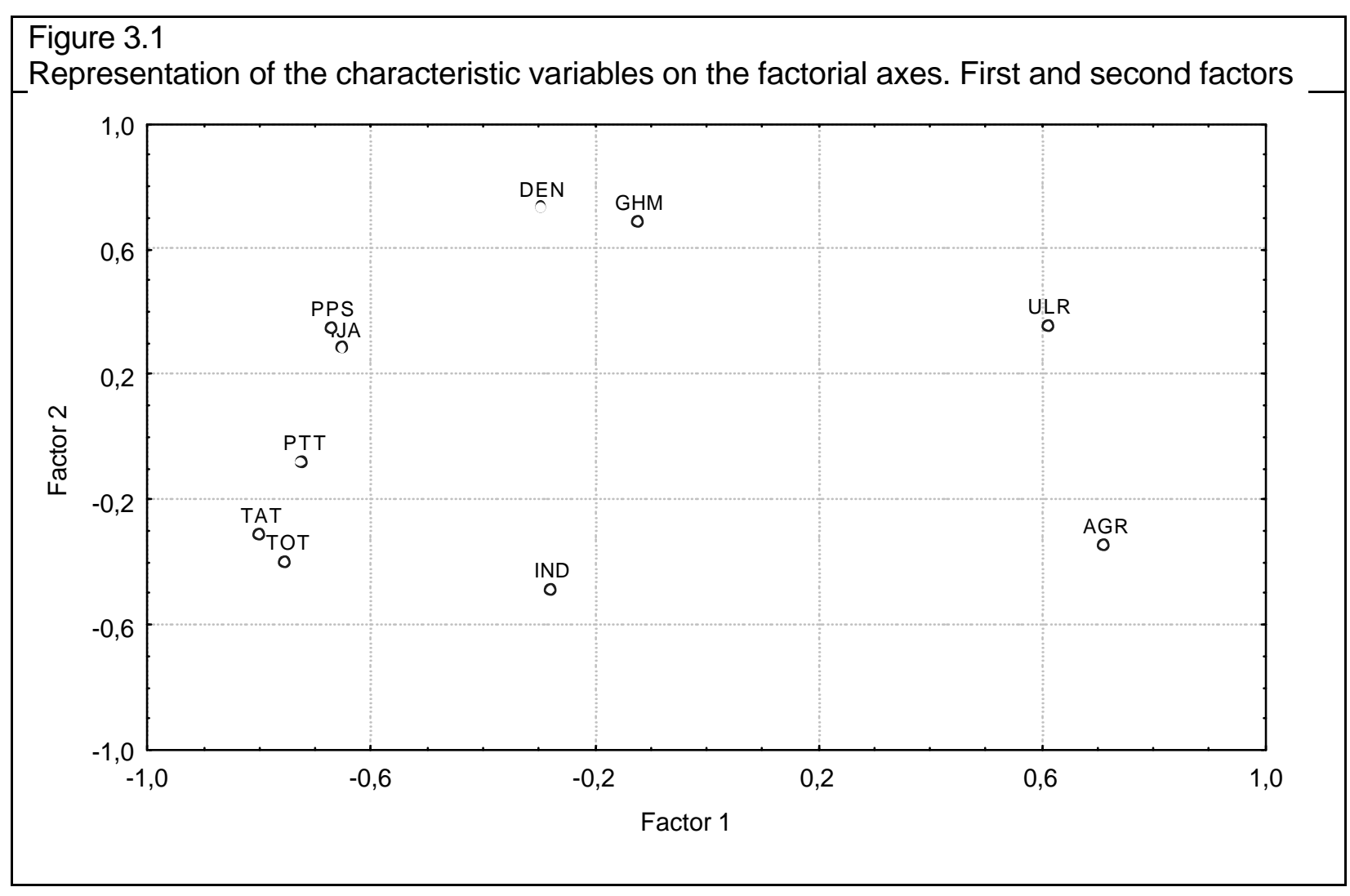




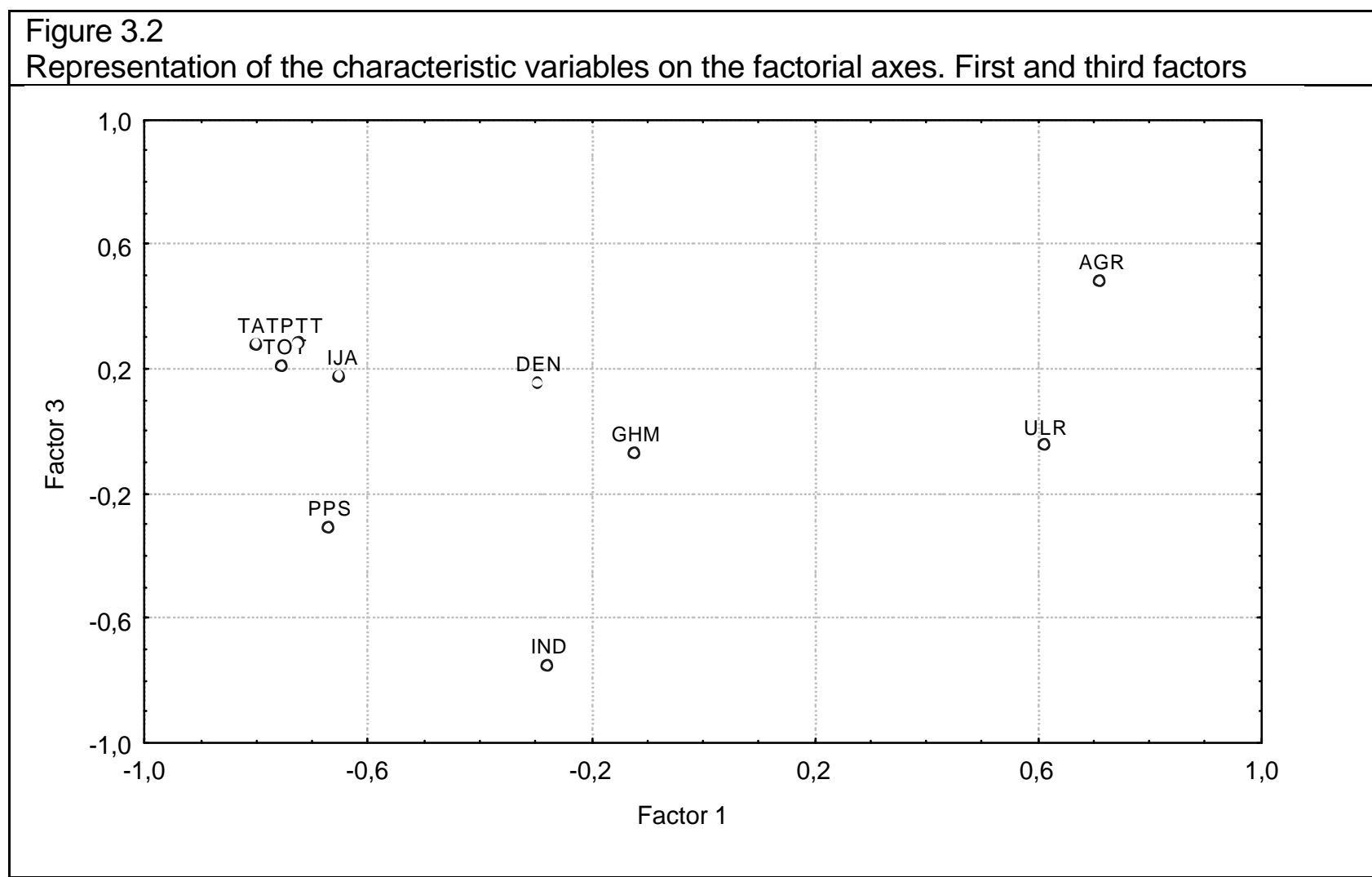


Along the second axis one observes a close correlation among, on the one hand (positive quadrant), population density (DEB), per capita income (PPS), and the percentages of employment in traditional services (GHM) and advanced services (IJA), and on the other (negative quadrant), percentage of employment in industry (IND) and in agriculture (AGR), and the employment rate (TOT). In this case, we may state that the second axis identifies in marked manner only the phenomena representing variables located in the positive quadrant, namely those correlated with the territorial dimension. In fact, the indicators in this quadrant represent highly urbanized areas, or ones which contain rail or road infrastructures or sea ports, or with high levels of tourism. The negative quadrant, by contrast, comprises indicators which are more difficult to interpret and concern a mix of factors, such as low population density, the presence of agricultural employment, and high levels of industry.

The phenomenon of industrialization, however, is thrown in sharpest relief by the third factor. This latter, in fact, is closely correlated in the negative quadrant with the percentage of employment in industry (IND), while in the positive quadrant one finds, once again, a close correlation with variables denoting various characteristics: high percentage of employment in agriculture (AGR), but also a good labour market structure - high percentage of part-time employment (PTT), high employment rate (TOT), and high participation rate (TAT). 


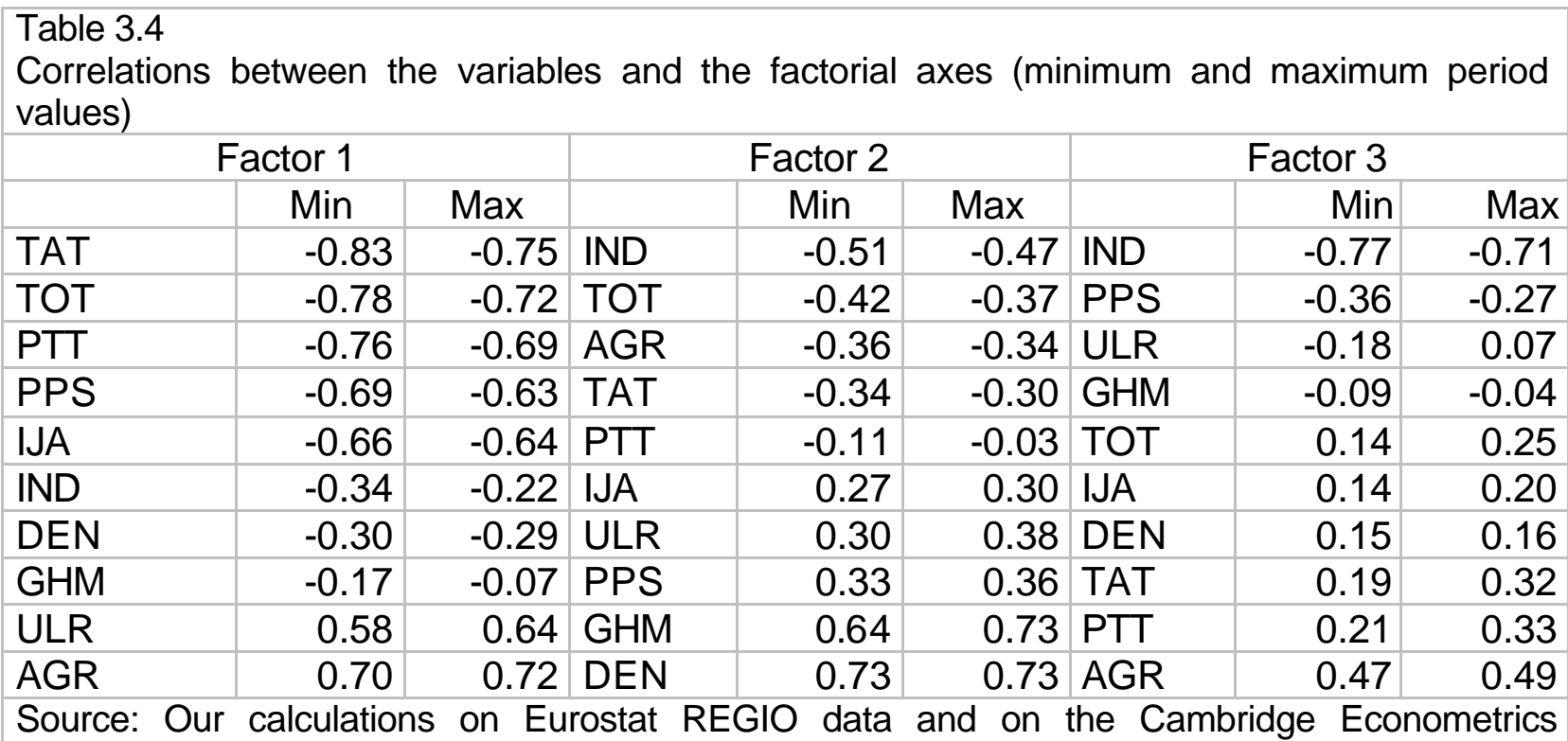

Source: Our calculations on Eurostat REGIO data and on the Cambridge Econometrics database 


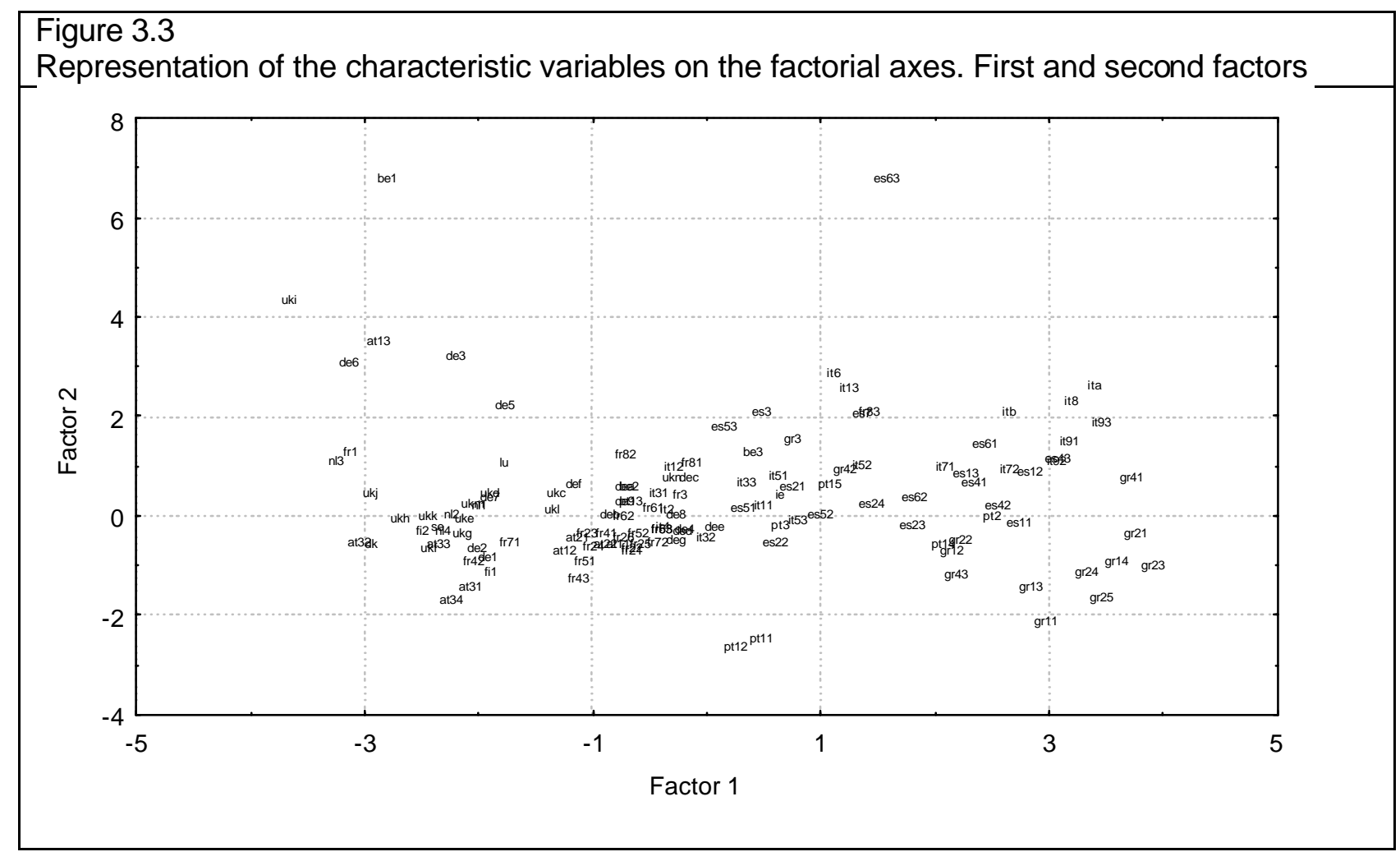




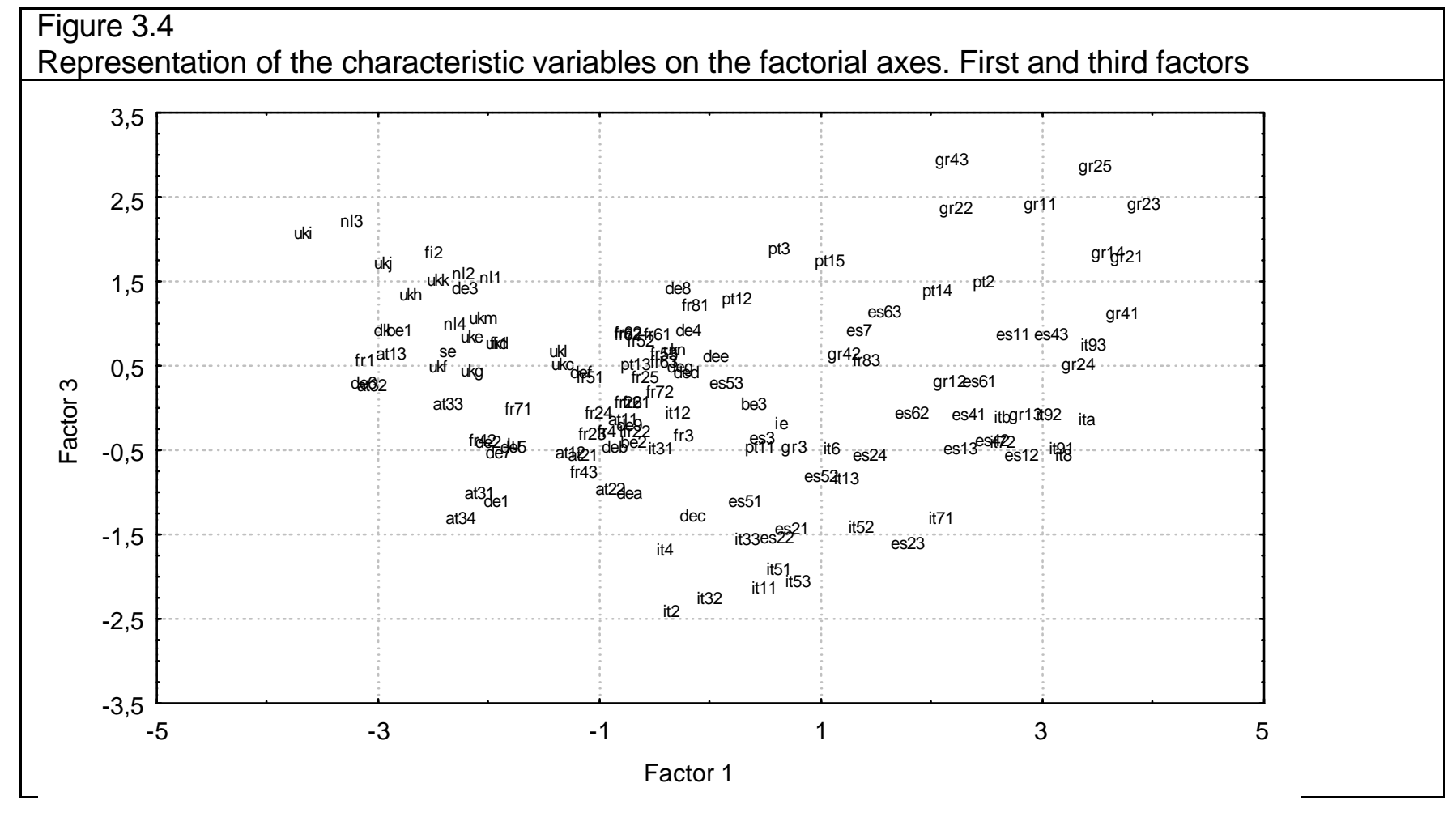


Figures 3.3. and 3.4 show the European regions on, respectively, the first two factorial axes and the first and the third. In this case, too, in order to interpret the figures we may refer to maps 3.5, 3.6 and 3.7, where the regions are given colours which diminish in intensity according to their position along the factorial axis from positive to negative. Moreover, in order to enable further comparison, the borders of the Objective 1 regions have been outlined in white. It will be seen from Figure 3.5, which shows the positions of the regions along the first factor, there is a marked contrast between the majority of the Objective 1 regions, which lie in the positive quadrant of the axis and are therefore characterized by high structural unemployment and/or a high percentage of employment in agriculture, and the central-northern regions of Europe and of central-southern England, which are characterized by dynamic labour markets producing high levels of employment and participation, and with pronounced institutional flexibility. Occupying an intermediate position are the majority of the French regions and those of northern Italy and north-western Germany, which may have both dynamic labour markets and a high proportion of employment in agriculture, or even high percentages of long-term unemployment. Also to be emphasised is that large part of these latter regions, together with those of East Germany and Ireland, and some Spanish regions, contribute to a minimal extent $(<0.09 \%)$ to the formation of the first factor. We may therefore conclude that the Objective 1 regions, especially those of the Mediterranean basin and central-northern Europe, distinctively characterize the first factor.

The positions of the regions along the second factorial axis are much more diversified. As said, the regions lying in the positive quadrant are those associated with localization factors (high population density, employment in services, and high incomes), while the characterization of the regions in the negative quadrant is less clear-cut. In fact, it will be seen in Figure 3.6 that the regions with the darkest colouring in the first quadrant are those which comprise the main European capital cities, important transport infrastructures, or with particularly developed tourist industries. 
Figure 3.5

Map of the First Factor

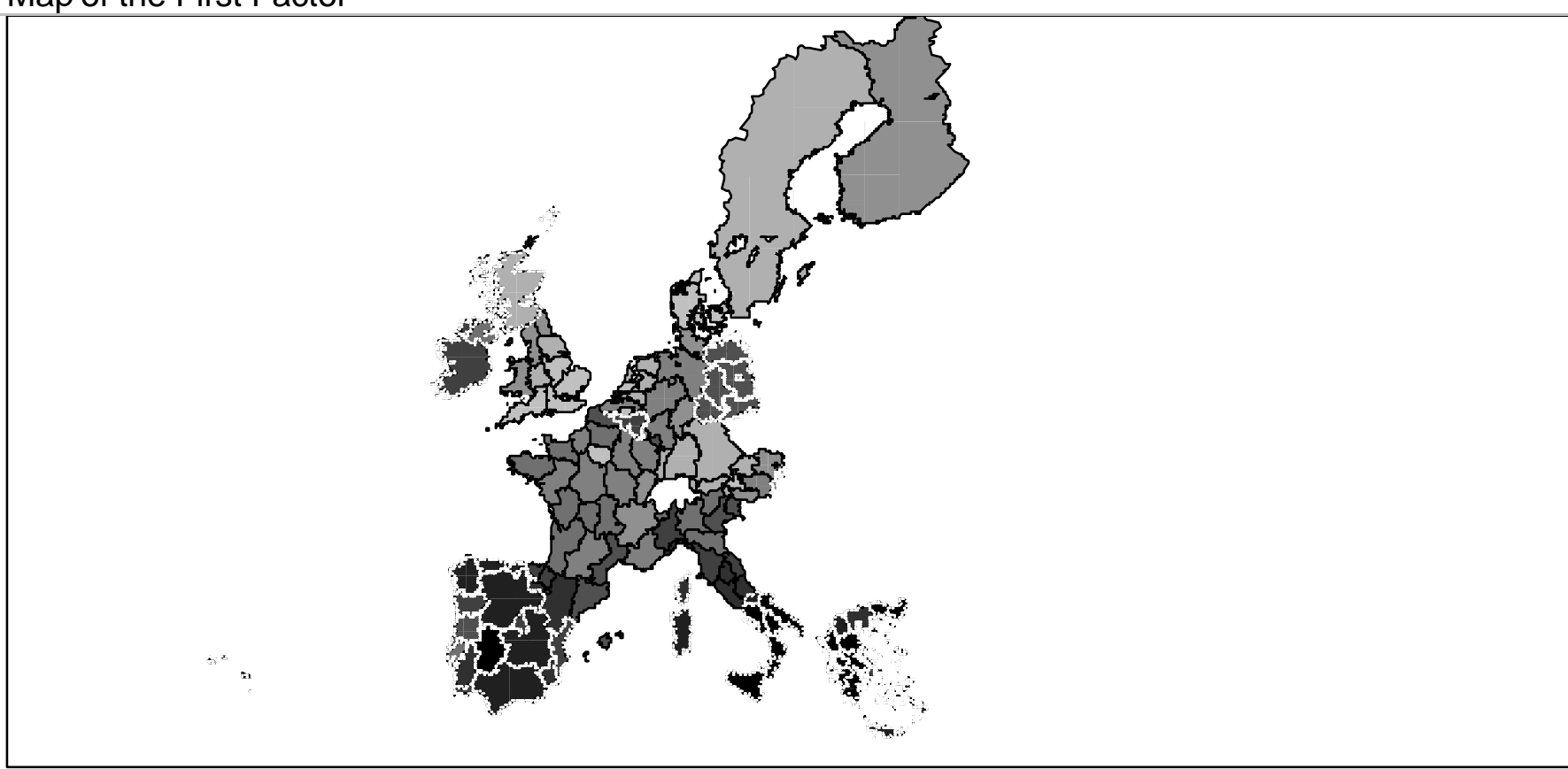

Source: Our calculations on Eurostat REGIO data and on the Cambridge Econometrics database The borders of the Objective 1 regions are outlined in white 


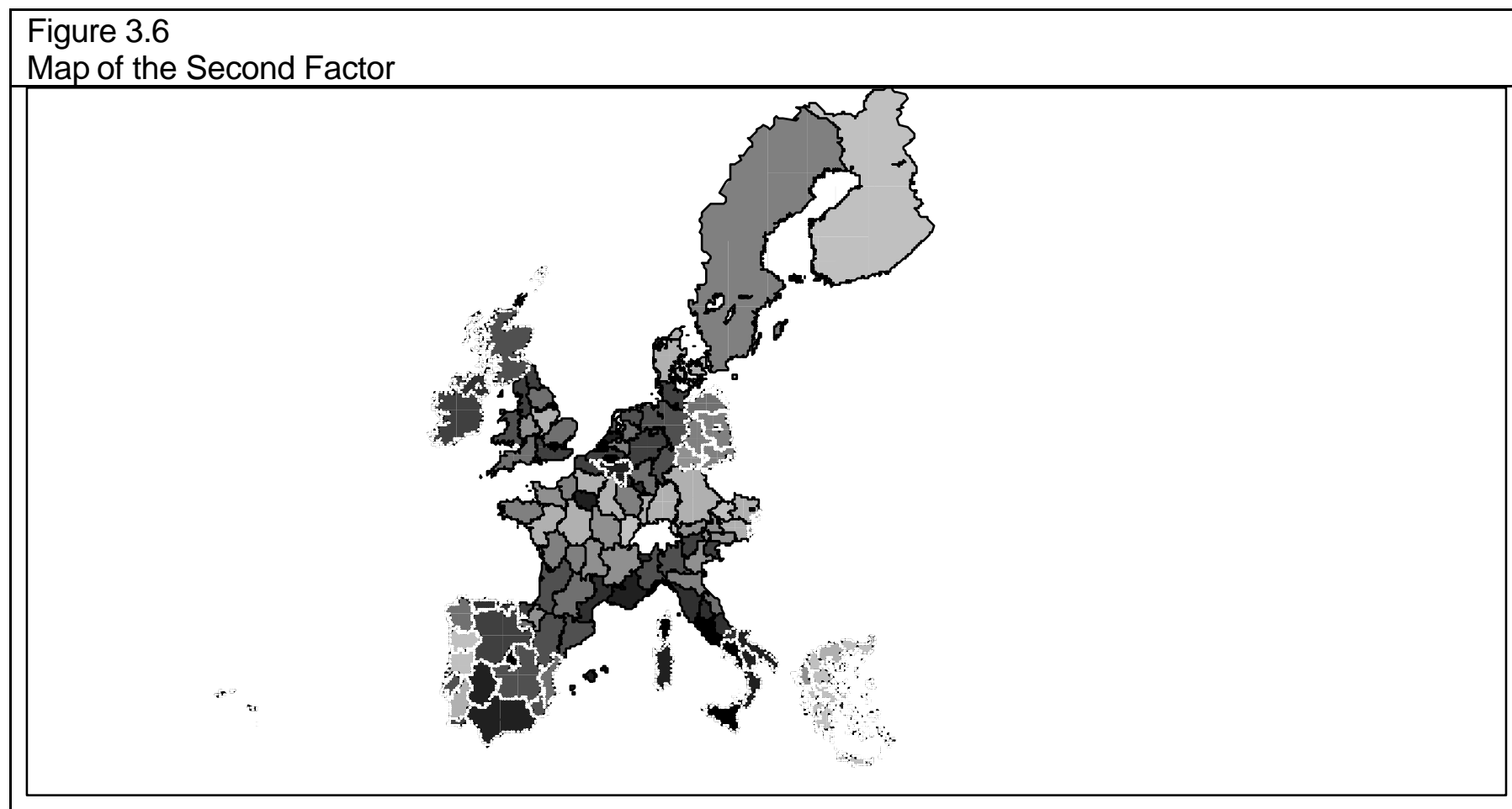

Source: Our calculations on Eurostat REGIO data and on the Cambridge Econometrics database The borders of the Objective 1 regions are outlined in white 


\section{Figure 3.7}

Map of the Third Factor

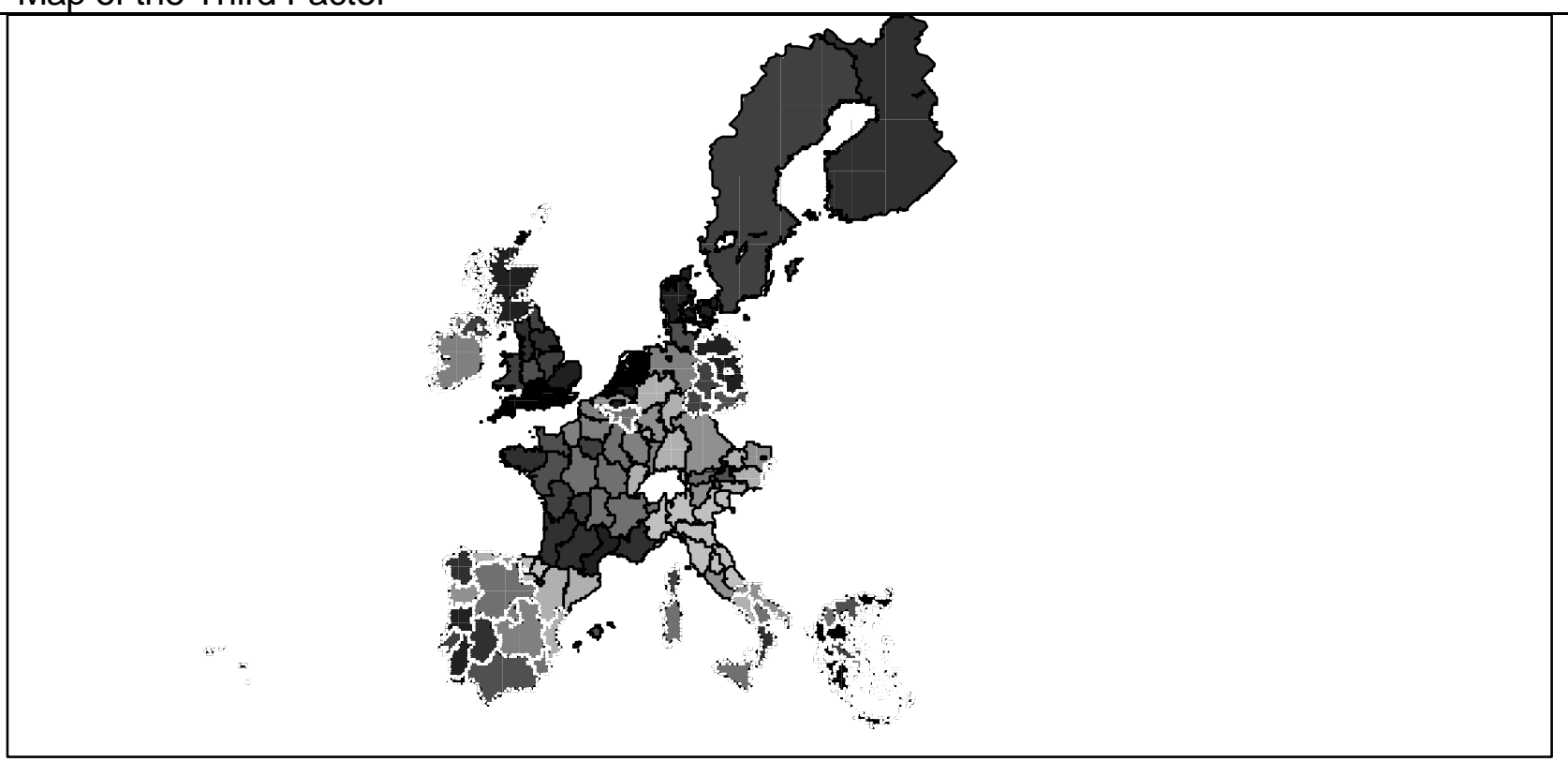

Source: Our calculations on Eurostat REGIO data and on the Cambridge Econometrics database The borders of the Objective 1 regions are outlined in white 
Also as regards the third factor, clear interpretation can only be made of the positions of the regions located in one of the two quadrants: in this case the negative one, which is characterized by indices of high levels of industrialization. In fact, the regions with the lightest colouring are those that can be associated with a high percentage of industrial employment: the central and north-eastern regions of Italy, the regions of central Germany, Austria, and the north-eastern regions of Spain.

A further result of the intrastructure phase analysis concerns the temporal trajectories followed by individual regions along the factorial axes and which highlight certain characteristics of the regional dynamic. A summary of these phenomena is provided by Tables 3.5 and 3.6, which show - for each year and only for the first two factors - the sum of the square of the distances between the individual regions and the factorial axis, weighted for the region's contribution to formation of that axis. In this way greater importance is given to the paths followed by the regions making the greatest contribution to defining the factor. The distances have been separately calculated for all regions, for those considered to be the core regions, for those in the EU periphery (cf. Basile and Kostoris Padoa Schioppa, 2002), and for the subgroup of the Objective I regions.

A first general phenomenon to be observed is that whilst for factor 1 the total distance increased during the decade for all the groups of regions considered, it diminished for factor 2. This seems to indicate that the regions gradually moved closer to the phenomena characterizing the second factor.

A second feature to be noted is that the distances of the core regions from both axes are much smaller than are those of the peripheral regions (and of the Objective 1 regions, to which category most of them belong). This means that the former are concentrated much more towards the centre of the axes, and therefore display a certain amount of homogeneity, while the latter lie more towards the extremes, and therefore display a greater structural characterization.

The third feature to stress is that the pattern of the distances is prevalently cyclical. The distances from the first factor are marked by shocks $(1993,1997,2000)$ followed by slow and only partial 
recoveries in subsequent years, whereas as regards the second factor, the shocks are less pronounced and the dynamic is more constant. In the latter case, moreover, the core regions display a pattern opposite to that of the others: in fact their distances, with the exception of the final three years, tend to increase. 
Table 3.5

Weighted average annual distances of the regions from the First Factorial Axis

\begin{tabular}{|c|c|c|c|c|c|c|c|c|}
\hline Year & $\begin{array}{c}\text { All the } \\
\text { Regions }\end{array}$ & $\begin{array}{c}\text { Index } \\
\text { Number } \\
91=100\end{array}$ & $\begin{array}{c}\text { Objective } \\
1\end{array}$ & $\begin{array}{c}\text { Index } \\
\text { Number } \\
91=100\end{array}$ & Core & $\begin{array}{c}\text { Index } \\
\text { Number } \\
91=100\end{array}$ & Periphery & $\begin{array}{c}\text { Index } \\
\text { Number } \\
91=100\end{array}$ \\
\hline 1991 & 6,86 & 100,00 & 4,31 & 100,00 & 2,36 & 100,00 & 4,50 & 100,00 \\
\hline 1992 & 7,06 & 102,99 & 4,48 & 104,05 & 2,38 & 100,83 & 4,69 & 104,22 \\
\hline 1993 & 7,74 & 112,85 & 4,91 & 114,13 & 2,59 & 109,80 & 5,15 & 114,44 \\
\hline 1994 & 7,34 & 107,01 & 4,62 & 107,20 & 2,49 & 105,54 & 4,85 & 107,78 \\
\hline 1995 & 7,64 & 111,41 & 4,73 & 109,75 & 2,54 & 107,80 & 5,10 & 113,33 \\
\hline 1996 & 7,54 & 110,03 & 4,72 & 109,61 & 2,60 & 110,46 & 4,94 & 109,78 \\
\hline 1997 & 8,11 & 118,22 & 5,07 & 117,69 & 2,86 & 121,31 & 5,25 & 116,67 \\
\hline 1998 & 7,72 & 112,54 & 4,72 & 109,52 & 2,78 & 118,03 & 4,94 & 109,78 \\
\hline 1999 & 7,77 & 113,36 & 4,83 & 112,05 & 2,72 & 115,48 & 5,05 & 112,22 \\
\hline 2000 & 8,12 & 118,47 & 5,14 & 119,31 & 2,70 & 114,62 & 5,42 & 120,44 \\
\hline
\end{tabular}

Source: Our calculations on Eurostat REGIO data and on the Cambridge Econometrics database 
Table 3.6

Weighted average annual distances of the regions from the Second Factorial Axis

\begin{tabular}{|r|r|r|r|r|r|r|r|r|}
\hline Year & $\begin{array}{c}\text { All the } \\
\text { Regions }\end{array}$ & $\begin{array}{c}\text { Index } \\
\text { Number } \\
91=100\end{array}$ & $\begin{array}{r}\text { Objective } \\
1\end{array}$ & $\begin{array}{c}\text { Index } \\
\text { Number } \\
\text { '91=100 }\end{array}$ & \multicolumn{1}{c|}{ Core } & $\begin{array}{c}\text { Index } \\
\text { Number } \\
\text { '91=100 }\end{array}$ & Periphery & $\begin{array}{c}\text { Index } \\
\text { Number } \\
91=100\end{array}$ \\
\hline 1991 & 9,79 & 100,00 & 8,01 & 100,00 & 1,71 & 100,00 & 8,08 & 100,00 \\
\hline 1992 & 9,70 & 99,06 & 7,83 & 97,67 & 1,80 & 105,30 & 7,90 & 97,74 \\
\hline 1993 & 9,43 & 96,26 & 7,49 & 93,42 & 1,86 & 109,23 & 7,56 & 93,52 \\
\hline 1994 & 9,23 & 94,28 & 7,38 & 92,13 & 1,76 & 103,37 & 7,47 & 92,36 \\
\hline 1995 & 9,05 & 92,41 & 7,22 & 90,14 & 1,74 & 101,78 & 7,31 & 90,44 \\
\hline 1996 & 8,65 & 88,37 & 6,79 & 84,78 & 1,79 & 104,87 & 6,86 & 84,89 \\
\hline 1997 & 9,17 & 93,66 & 7,29 & 91,00 & 1,81 & 105,77 & 7,37 & 91,10 \\
\hline 1998 & 8,97 & 91,64 & 7,23 & 90,28 & 1,65 & 96,81 & 7,32 & 90,55 \\
\hline 1999 & 8,58 & 87,65 & 6,85 & 85,47 & 1,66 & 97,01 & 6,93 & 85,67 \\
\hline 2000 & 7,69 & 78,57 & 6,04 & 75,35 & 1,60 & 93,64 & 6,10 & 75,39 \\
\hline
\end{tabular}

Source: Our calculations on Eurostat REGIO data and on the Cambridge Econometrics database 


\section{Summary and conclusions}

The results of the analysis confirm the thesis of those who contend that the European economy is a diversified reality influenced by structural phenomena concerning labour market characteristics, sectoral composition, and localization factors which make it unlikely that integration processes - although accelerated by the enlargement of markets and their greater efficiency - will give rise to the hoped-for levelling of economic development in the near future. The main reason for regional differences still seems to be the composition and structure of labour market. To be noted in particular is the marked contrast between the Mediterranean regions, most of which belong to the Objective 1 regions, and their high rates of structural unemployment, and the regions of centralnorthern Europe and central-southern England characterized by more flexible labour markets and high employment rates.

However, there are other phenomena responsible for regional disparities in Europe: localization factors (large conurbations, transport hubs, and tourism) which foster the development of connected service activities, and the presence of a solid industrial base accompanied by high levels of income and employment. These factors are associated with regions which are more territorially dispersed and therefore unlikely to form regional clusters, whilst, by contrast, industrialization phenomena are distributed across a transnational area formed by contiguous regions. This area stretches eastwards from the north-eastern regions of Spain along the Adriatic and through north-eastern Italy, and then northwards to the central regions of Europe, Austria and Germany. The dynamic analysis has shown not so much convergence as slow change in the structural characteristics that differentiate the regions of Europe, where localization factors and sectoral composition will probably be more influential in the future. Moreover, the peripheral regions seem to be more markedly characterized by structural differences than are the core regions. 


\section{Appendix}

Table A.1

List of the 130 European regions used in the STATIS analysis.

The country in which they are located and the corresponding NUTS level are indicated in bold.

\begin{tabular}{|l|l|l|l|}
\hline sigla & Regioni & sigla & Regioni \\
\hline be1 & $\begin{array}{l}\text { Relgium - NUTS 1 - Regions } \\
\text { Région Bruxelles- } \\
\text { capitale/Brussels hoofdstad } \\
\text { gewest }\end{array}$ & be2 & Vlaams Gewest \\
\hline be3 & Région Wallonne & & \\
\hline Dk & Denmark - NUTS 0 - Nation & & \\
\hline & $\begin{array}{l}\text { Federal Republic of Germany (including ex-GDR from 1991) } \\
\text { - NUTS 1 - Lander }\end{array}$ & \\
\hline de1 & Baden-Württemberg & de2 & Bayern \\
\hline de3 & Berlin & de4 & Brandenburg \\
\hline de5 & Bremen & de6 & Hamburg \\
\hline de7 & Hessen & de8 & Mecklenburg-Vorpommern \\
\hline de9 & Niedersachsen & dea & Nordrhein-Westfalen \\
\hline deb & Rheinland-Pfalz & dec & Saarland \\
\hline Ded & Sachsen & dee & Sachsen-Anhalt \\
\hline Def & Schleswig-Holstein & deg & Thüringen \\
\hline & Greece - NUTS 2 - Development regions \\
\hline gr11 & Anatoliki Makedonia, Thraki & gr12 & Kentriki Makedonia \\
\hline gr13 & Dytiki Makedonia & gr14 & Thessalia \\
\hline gr21 & Ipeiros & gr22 & lonia Nisia \\
\hline gr23 & Dytiki Ellada & gr24 & Sterea Ellada \\
\hline gr25 & Peloponnisos & gr3 & Attiki \\
\hline gr41 & Voreio Aigaio & gr42 & Notio Aigaio \\
\hline gr43 & Kriti & & \\
\hline & Spain - NUTS 2 - Comunidades autonomas \\
\hline es11 & Galicia & es12 & Principado de Asturias \\
\hline es13 & Cantabria & es21 & Pais Vasco \\
\hline es22 & Comunidad Foral de Navarra & es23 & La Rioja \\
\hline es24 & Aragón & es3 & Comunidad de Madrid \\
\hline & \multicolumn{2}{|l}{} & \\
\hline
\end{tabular}




\begin{tabular}{|l|l|l|l|}
\hline es41 & Castilla y León & es42 & Castilla-la Mancha \\
\hline es43 & Extremadura & es51 & Cataluña \\
\hline es52 & Comunidad Valenciana & es53 & Baleares \\
\hline es61 & Andalucia & es62 & Murcia \\
\hline es63 & Ceuta y Melilla (ES) & es7 & Canarias (ES) \\
\hline & France - NUTS 2 - Régions & \multicolumn{2}{|l|}{} \\
\hline fr1 & Île de France & fr21 & Champagne-Ardenne \\
\hline fr22 & Picardie & fr23 & Haute-Normandie \\
\hline fr24 & Centre & fr25 & Basse-Normandie \\
\hline fr26 & Bourgogne & fr3 & Nord - Pas-de-Calais \\
\hline fr41 & Lorraine & fr42 & Alsace \\
\hline fr43 & Franche-Comté & fr51 & Pays de la Loire \\
\hline fr52 & Bretagne & fr53 & Poitou-Charentes \\
\hline fr61 & Aquitaine & fr62 & Midi-Pyrénées \\
\hline fr63 & Limousin & fr71 & Rhône-Alpes \\
\hline fr72 & Auvergne & fr81 & Languedoc-Roussillon \\
\hline fr82 & Provence-Alpes -Côte d'Azur & fr83 & Corse \\
\hline le & Ireland - NUTS 0 - Nations & & \\
\hline & Italy - NUTS 2 - Regioni & & \\
\hline it11 & Piemonte & it12 & Valle d'Aosta \\
\hline it13 & Liguria & it2 & Lombardia \\
\hline it31 & Trentino-Alto Adige & it32 & Veneto \\
\hline it33 & Friuli-Venezia Giulia & it4 & Emilia-Romagna \\
\hline it51 & Toscana & it52 & Umbria \\
\hline it53 & Marche & it6 & Lazio \\
\hline it71 & Abruzzo & it72 & Molise \\
\hline it8 & Campania & it91 & Puglia \\
\hline it92 & Basilicata & it93 & Calabria \\
\hline Ita & Sicilia & itb & Sardegna \\
\hline Lu & Luxembourg & \multicolumn{2}{|l|}{} \\
\hline & Netherlands - NUTS 2 - Provincies \\
\hline nl1 & Noord-Nederland & nl2 & Oost-Nederland \\
\hline nl3 & West-Nederland & nl4 & Zuid-Nederland \\
\hline & Austria - NUTS 0 - Bundesländer & \\
\hline at11 & Burgenland & at12 & Niederösterreich \\
\hline at13 & Wien & at21 & Kärnten \\
\hline at22 & Steiermark & at31 & Oberösterreich \\
\hline at32 & Salzburg & at33 & Tirol \\
\hline & & & \\
\hline
\end{tabular}




\begin{tabular}{|c|c|c|c|}
\hline \multirow[t]{2}{*}{ at34 } & Vorarlberg & & \\
\hline & \multicolumn{3}{|c|}{ Portugal - NUTS 0 - NUTS 2 groupings } \\
\hline pt11 & Norte & pt12 & Centro (P) \\
\hline pt13 & Lisboa e Vale do Tejo & pt14 & Alentejo \\
\hline pt15 & Algarve & pt2 & Açores (PT) \\
\hline \multirow{2}{*}{ pt3 } & Madeira (PT) & & \\
\hline & \multicolumn{3}{|c|}{ Finland- NUTS 1 - Manner-Suomi/Ahvenanmaa } \\
\hline fi1 & Manner-Suomi & fi2 & Åland \\
\hline \multirow[t]{2}{*}{ se } & \multicolumn{3}{|l|}{ Sweden- NUTS 0 - Nation } \\
\hline & \multicolumn{3}{|c|}{ United Kingdom -NUTS 1 - Nation } \\
\hline ukc & North East & ukd & $\begin{array}{l}\text { North West (including } \\
\text { Merseyside) }\end{array}$ \\
\hline uke & Yorkshire and The Humber & ukf & East Midlands \\
\hline ukg & West Midlands & ukh & Eastern \\
\hline uki & London & ukj & South East \\
\hline ukk & South West & ukl & Wales \\
\hline ukm & Scotland & ukn & Northern Ireland \\
\hline
\end{tabular}


Map of the European regions with the relative abbreviations

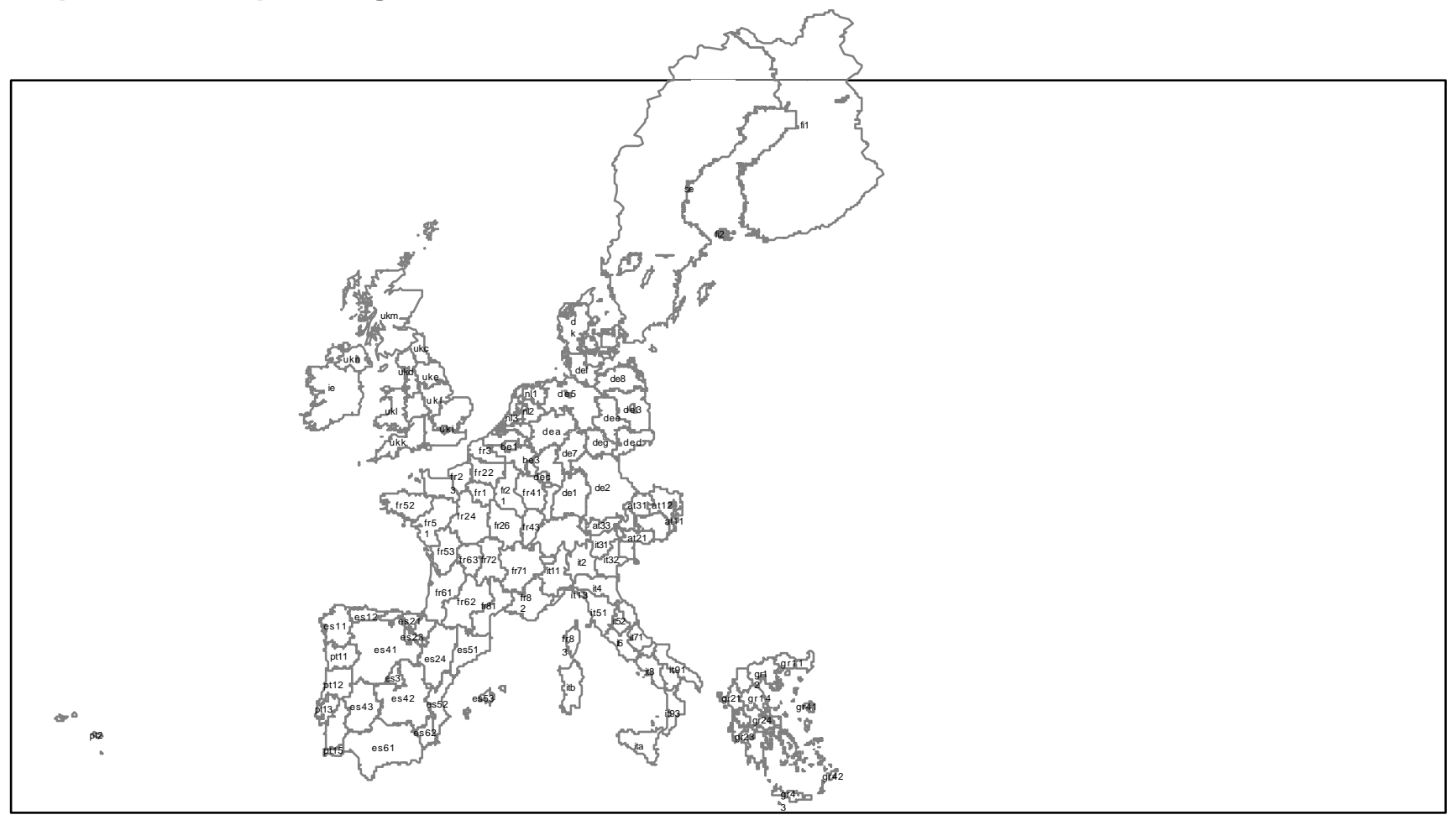




\section{Riferimenti bibliografici}

Amendola A., Caroleo F.E., Coppola G. (1999), "Differenziali territoriali nel mercato del lavoro e sviluppo in Italia", in Biagioli M. e al. (a cura di), Struttura della contrattazione differenziali salariali e occupazione in ambiti regionali, Collana AIEL, ESI Edizioni, Napoli

Baffigi A. (1999), I differenziali territoriali nella struttura dell'occupazione e della disoccupazione: un'analisi con dati a livello provinciale (1981-1995), in Biagioli M. e al. (a cura di), Struttura della contrattazione differenziali salariali $e$ occupazione in ambiti regionali, Collana AIEL, ESI Edizioni, Napoli.

Barro R.J., Sala-i-Martin, X. (1991), "Convergence across States and Regions", Brookings Papers on Economic Activity n.1, 107-182.

Basile R., de Nardis S., Girardi A. (2003), "Dinamiche di sviluppo nel centro e nella periferia d'Europa: il ruolo delle politiche strutturali", Rivista di Politica Economica n.4, 89-134

Blanchard O. J., Katz L. F. (1992), "Regional Evolutions", Brooking Papers on Economic Activity, n.1, 1-61.

Boldrin M. and Canova F. (2001), "Inequality and Convergence in Europe's Regions: Reconsidering European Regional Policies", Economic Policy, April, 207-253.

Canova F., (2001) "Are EU Policies Fostering Growth and Reducing Regional Inequalities?" Els opuscles del CREI, n. 8 May.

Combes P.P., Overman H.G. (2003), "The Spatial Distribution of Economic Activities in the European Union", draft chapter for forthcoming Handbook of Urban and Regional Economies, vol. 4, Henderson V., Thisse J. (eds).

Cuadraro Rura J.R., (2001), Regional Convergence in the European Union: From Hypothesis to the Actual Trends, The Annals of Regional Science, vol.35.

D’Ambra L. (1985), "Alcune estensioni dell'analisi in componenti principali per lo studio di sistemi evolutivi, Uno studio sul 
commercio internazionale dell'elettronica", Ricerche Economiche n.2, 233-260.

Daniele V., (2002), "Integrazione economica e monetaria e divari regionali nell'Unione Europea", Rivista Economica del Mezzogiorno, n. 3, 513-550.

Davies S., Hallet M. (2001), "Policy responses to regional unemployment: lessons from Germany, Spain, Italy, European Commission", Directorate-Generale for Economic and Financial Affairs, Economic Papers n.161 October.

Davies S., Hallet M. (2002), "Interactions between National and Regional Development", HWWA Discussion Paper, n. 207.

De la Fuente A. (2000), "Convergence across Countries and Regions: Theory and Empirics", European Investment Bank Papers, n.2.

De la Fuente A.; (2002), "The effect of Structural Fund spending on the Spanish Regions: an assessment of the 1994-99 Objective 1" CSF, CSIC Working Paper.

Decressing, J., Fatàs A., (1995), "Regional Labor Market Dynamics in Europe", European Economic Review. n. 3 1627-1655,

Edervee S., Gorter J., (2002), "Does European Cohesion Policy Reduce Regional Disparities? An Empirical Analysis", CPB Discussion Paper, n. 15.

Elhorst J.P. (2000), "The Mystery of Regional Unemployment Differentials: a Survey of Theoretical and Empirical Explanations", Research Report 00C06, University of Groningen, Research Institute SOMTheme C: Coordination and Growth in Economics.

Escoufier Y. (1985), "Statistique et analyse des données", Bulletin des Statisticiens Universitaires, vol.10, n.1

Escoufier Y. (1987), "Three-mode Data Analysis: the Statis Method", in: Methods for Multidimensional Data Analysis, European Courses in Advanced Statistics. 
European Commission (2000), "Real Convergence and Catching up in the EU"in: The EU Economy: 2000 Review, European Commission, Luxembourg.

Fachin S. Vichi M. (1994), "Deindustrializzazione, specializzazione o ristrutturazione? Una analisi multiway in matrici fattoriali dell'evoluzione dell'industria manifatturiera italiana dal 1971 al 1983", Politica Economica, vol. 10,.pp 373-404

Genre V., Gòmez-Salvador R. (2002), "Labour Force Developments in the Euro Area Since the 1980s" ECB Occasional Paper Series, n.4 July.

Greenway D., Upward R., Wright P. (2002), "Structural Adjustment and the Sectoral and Geographical Mobility of Labour", Leverhulme Centre for Research on Globalisation and Economic Policy Working Paper, n. 3, University of Nottingham.

Hyclak T., Johnes G. (1987), "On the Determinants of Full Employment Unemployment Rates in Local Labour Markets", Applied Economics, 19, 615-645.

Kostoris Padoa Schioppa F. (1999), "Regional Aspects of Unemployment in Europe and in Italy", CEPR Discussion Paper, n.2108.

Kostoris Padoa Schioppa F., Basile R. (2002), "Dinamiche della disoccupazione nei "Mezzogiorni d'Europa": quali lezioni per il Mezzogiorno d'Italia?", Rivista di Politica Economica, Maggio-Giugno, 83-124.

Marelli E. (2003), "Regional employment dynamics in the EU: structural outlook, co-movements, clusters and common shocks", International Conference of the Regional Studies Association, Pisa.

Martin P., (1998) "Can Regional Policies Affect Growth and Geography in Europe?", The World Economy, vol. 21, n.6, 757-774

Niebuhr A. (2002), "Spatial Dependence of Regional Unemployment in the European Union", HWWA Discussion Paper, n. 186. 
Obstfeld M., Peri G. (1998), "Regional non-adjustment and fiscal policy", Economic Policy, April, 205-47.

Overman H. G., Puga D. (2002), "Unemployment Clusters Across European Regions and Countries", Economic Policy, April, 117-147.

Paci R. and Pigliaru F. (1999), "European Regional Growth: Do Sectors Matter? in Adams J., Pigliaru F.(eds) (1999), Economic Growth and Change, National and Regional Patterns of Convergence and Divergence, E. Elgar, Calthenam.

Paci R., Pigliaru F., Pugno M. (2002), Le disparità nella crescita economica e nella disoccupazione tra le regioni europee: una prospettiva settoriale in Farina F., Tamborini R. (a cura di), (2002), Da Nazioni a Regioni: Mutamenti istituzionali e strutturali dopo l'Unione Monataria Europea, II Mulino, Bologna.

Pench L.R., Sestito P., Frontini E. (1999), "Some Unpleasant Arithmetics of Regional Unemployment in the EU, Are there Any Lessons for EMU?", Unione Europea DG XII, Brussel.

Rizzi A.(1989), Analisi dei dati, La Nuova Italia Scientifica

Sala-I-Martin X. (1996), "Regional Cohesion: Evidence and Theories of Regional Growth and Convergence", European Economic Review, n. 40, 1325-1352.

Tassinari G., Vichi M. (1994), "La dinamica economica dei paesi avanzati negli anni ottanta: Riflessioni sulle traiettorie risultanti dalle analisi delle matrici a tre vie", Giornale degli Economisti e Annali di Economia, 1-3.

Taylor J., Bradley S. (1997), "Unemployment in Europe: A Comparative Analysis of Regional Disparities in Germany, Italy and the UK", Kyklos, vol.50, n. 2, 221-245.

Tondl G. (1997), "Regional Convergence in Europe during the Past 40 Years", EUI Working Papers, Feb.

Wishlade F., Yuill D. (1997), "Measuring Disparities for Area Designation Purposes: Issues for the European Union, 
Regional and Industrial Policy" Research Paper, n.24, University of Strathclyde. 